\title{
BARK BEETLES, FUELS, AND SHORT-INTERVAL FIRES IN Douglas-Fir ANd LODGEPOLE PINE FORESTS OF GREATER YELLOWSTONE
}

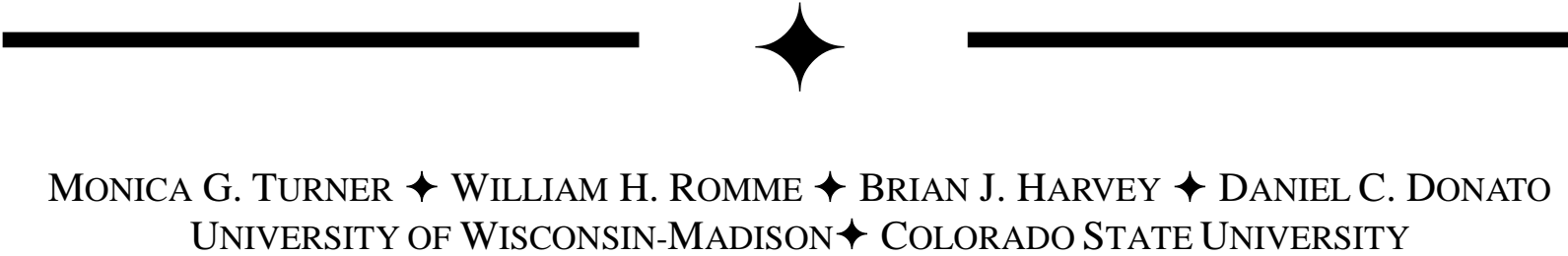

\section{$\uparrow \quad$ ABSTRACT}

Recent increases in insect and fire activity throughout the western US have presented forest managers with formidable challenges. The extent and severity of bark beetle (Curculionidae: Scolytinae) epidemics have reached unprecedented levels, and the frequency of large, severe fires continues to increase. These trends are expected to continue because climate change is implicated for both disturbances. Insects and fire have tremendous ecological and economic effects in western forests, yet surprisingly little is known about how fire hazard may change following bark beetle epidemics, and how changing fire regimes may potentially alter forests of Greater Yellowstone. We are employing a combination of field studies, remote sensing and simulation modeling to understand how bark beetle infestation affects fire hazard in Douglas-fir (Pseudotsuga menziesii) forests. The Douglas-fir type is a key component of Rocky Mountain landscapes, and is experiencing extensive and severe bark beetle outbreaks. However, almost no studies have examined Douglas-fir. We hypothesized that differences in fire regime, stand structure, regeneration potential and decomposition of woody fuels lead to important differences in fuel profiles, fire hazard and, in turn, the effectiveness of alternative mitigation strategies in Douglas-fir. Our studies are being conducted in Grand Teton and Yellowstone National Parks, and the Bridger-Teton and Shoshone National Forests within the Greater Yellowstone Ecosystem (GYE), where we build on $>20$ years of research and our recent studies of bark beetles and fire in lodgepole pine forests. During the summer of 2011, we conducted a significant portion of the field component of the project, collecting ancillary data in our previously measured chronosequence of Douglas-fir forests of differing time since beetle attack (TSB), and measuring burn severity and forest regeneration following a 2008 fire that burned a recently beetle-attacked Douglas-fir forest on the Shoshone National Forest. We also sampled forest regeneration and dead wood biomass following a short (28-year) interval 'reburn' in lodgepole pine forests to test whether reduced seed sources associated with younger trees at the time of burning might reduce postfire regeneration potential. Data analyses are ongoing and results will be forthcoming.

\section{$\downarrow \quad$ INTRODUCTION}

Recent increases in insect and fire activity throughout the western US have presented forest managers with formidable challenges. The extent and severity of bark beetle (Curculionidae: Scolytinae) epidemics have reached unprecedented levels and the frequency of large, severe fires continues to increase (Westerling et al. 2006). These trends are expected to continue because climate change-especially warmer temperatures, earlier snowmelt and more severe summer droughts-is implicated for both disturbances. Insects and fire have tremendous ecological and economic effects in western forests, yet their interaction is poorly understood. Surprisingly little is known about how fire hazard may change following bark beetle epidemics, and how changing fire regimes may potentially alter forests of Greater Yellowstone. Scientists have begun tackling these problems (e.g., Jenkins et al. 2008), but empirical 
data are scarce. Research has shown that time since beetle outbreak is critical for understanding the relationship between beetle outbreaks, stand structure, fuel dynamics and fire hazard, but again, empirical data are few. We are employing a powerful combination of field studies, remote sensing and simulation modeling to understand how bark beetle infestation and post-outbreak management affect fire hazard in Douglas-fir (Pseudotsuga menziesii) forests; very few studies have examined Douglas-fir. Our studies are being conducted in Grand Teton and Yellowstone National Parks, and the Bridger-Teton and Shoshone National Forests within the Greater Yellowstone Ecosystem (GYE), where we build on $>20$ years of research and our recent studies of bark beetles and fire in lodgepole pine forests.

A second factor that may affect forest resilience in the next century is increased frequency of wildfire. Shorter intervals between standreplacing fires may result in lower forest resilience (regeneration potential) if the fire interval is shorter than the time required for a mature seed bank to develop. Further, repeated fires may reduce ecosystem carbon storage by consuming a greater portion of woody biomass, an important legacy structure in young post-fire stands.

Lodgepole pine and Douglas-fir forests are key components of Rocky Mountain landscapes. Both are experiencing extensive and severe bark beetle outbreaks, yet important differences between these forest types (Keane 2008) suggest that postbeetle changes in fuel hazard may be distinct. We hypothesize that differences in fire regime, stand structure and regeneration potential lead to important differences in fuel profiles and fire hazard in lodgepole pine and Douglas-fir. We are focusing on changes in fuel profiles over time and the effects of insect outbreak on fire behavior (both recent and future). Collectively, we are directly addressing key bark beetle research priorities identified by US Forest Service scientists for the western US (Negron et al. 2008).

\section{Project Objectives and Hypotheses}

Question 1: How do bark beetle outbreaks affect fuel profiles and subsequent fire hazard in Douglas-fir forests? Bark beetle outbreaks substantially alter stand structure and live and dead fuel characteristics. We are beginning to understand how fuels and potential fire behavior change over time following mountain pine beetle outbreaks in lodgepole pine forests, based on data from our current research (Simard et al. 2011) and similar studies (Lynch et al. 2006, Page and Jenkins 2007a, 2007b, Jenkins et al. 2008). Major trends include an initial (3-5 yr post-outbreak) reduction in canopy bulk density and continuity, as dead needles fall from beetle-killed trees; and a later (20 yr post-outbreak) increase in large dead woody fuels as dead trees fall. Live herbaceous fuels may increase after the canopy is opened, and surviving trees (mostly understory individuals) may grow into the canopy after $20 \mathrm{yr}$, increasing ladder fuels. Studies in Utah and Idaho (Page and Jenkins 2007a, 2007b, Jenkins et al. 2008) found increased fine fuel loads that increased flame length early after beetle outbreak. Our data for lodgepole pine in the GYE indicate that the likelihood of active crown fire is reduced following beetle outbreak (Simard et al. 2011). Further, little research has addressed interior Douglas-fir forests, which are extensive in the Rockies and often coincide with locations where residential development is increasing. Given differences in structure and dynamics of lodgepole pine and Douglas-fir forests, we anticipate significant differences in post-beetle fuel dynamics and potential fire behavior, and our studies are underway.

Question 2: How was the severity of recent fire in Douglas-fir forests affected by prior bark beetle infestation, and does the combination of beetle infestation and fire compromise forest recovery? The ability to address directly the effects of beetle infestation on fire severity has been limited by a lack of spatially explicit data to characterize the extent and severity of both disturbances and an absence of field studies of fire in beetle-killed forests. Because the likelihood and severity of fire is affected by the timing of beetle infestation and may vary with forest type, there is a need to characterize the landscape heterogeneity of fuels created by bark beetle infestation in both space and time. Recent advances in remote sensing of forest ecosystems has led to the development of methods to accurately map both fire severity (e.g., Miller and Thode 2007) and the extent (e.g., Wulder et al. 2006) and severity (our work in prep) of bark beetle damage at broad scales. These advances provide the opportunity to test whether recent beetle damage has contributed to more severe fires in beetle-damaged areas, and these studies are underway.

Question 3: How do short-interval fires in lodgepole pine forests influence forest regeneration and ecosystem carbon storage? We hypothesize that tree regeneration would be much lower in the shortinterval fire compared to fires burning through mature forest, because of a reduced seed bank stored in serotinous cones. We also hypothesize a 
substantially reduced dead wood carbon pool in areas burned twice within a 28 -year time period.

\section{STUDY AREA}

Our study is being conducted within the GYE in northwestern Wyoming (Figure1), including Yellowstone (YNP) and Grand Teton National Parks and the Bridger-Teton (BTNF) and Shoshone (SNF) National Forests. The Douglas-fir beetle (DFB) has been active since 2002, and in addition to the wellknown 1988 fires, significant beetle-affected area has also burned recently. Also, the 2009 Bearpaw Fire in Grand Teton National Park burned over the 1981 Mystic Fire, creating an opportunity to study the impact of a 28 -year interval between stand-replacing fires, which is roughly an order of magnitude shorter than typical fire intervals in GYE lodgepole forests over the last few millennia. All work is being conducted under permits with both the national parks and national forests.

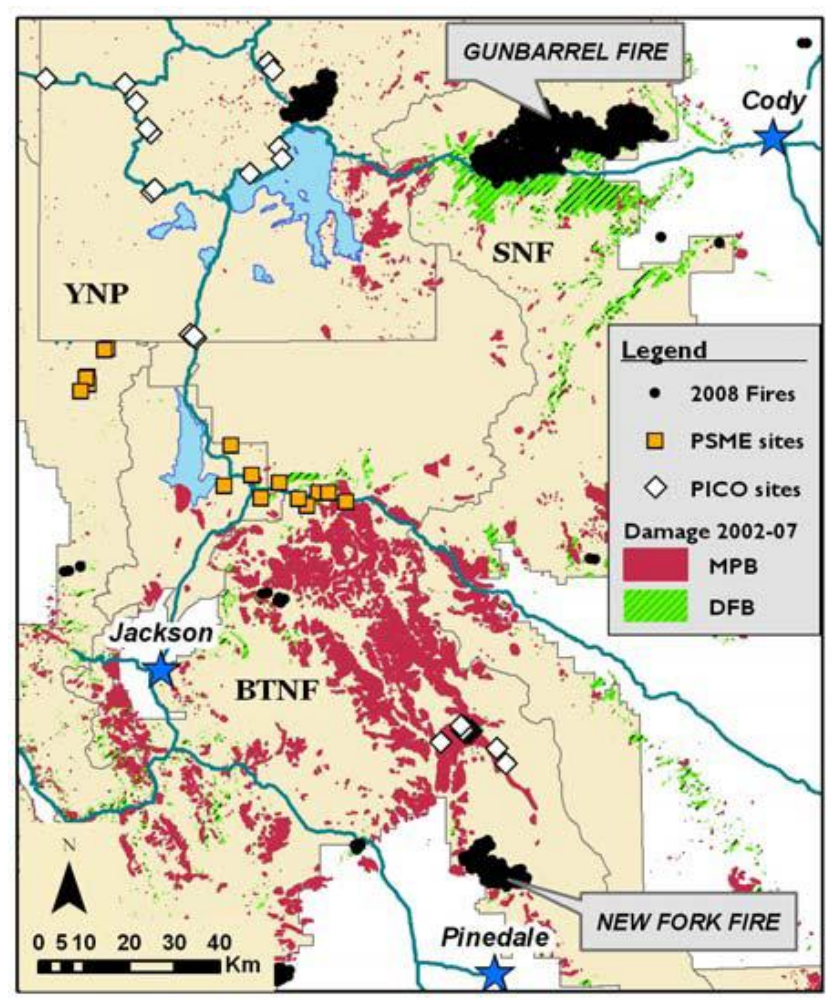

Figure 1. Study sites are located across much of Greater Yellowstone. Fire severity was sampled in two recent fires, along with remote sensing. The Gunbarrel Fire was sampled in the summer of 2011. A time-since-beetle chronosequence of Douglas-fir stands was augmented with dendrochronological sampling in 2011.

\section{$\uparrow \quad$ METHODS}

To assess fuel profiles and fire hazard in beetle-affected forest (Question 1), a "time-sincebeetle" (TSB) chronosequence was sampled in Douglas-fir forests of the GYE to quantify fuel profiles from 0 to $20 \mathrm{yrs}$ since the epidemic. Most of the fuel sampling was completed in 2010, but we augmented these data in the summer of 2011 via tree coring and collection of cross-sections of beetlekilled $\operatorname{logs}$, in order to validate the timing and severity of past outbreaks. Results are being compared to our existing data for lodgepole pine. We are developing remote sensing products to map the variation in canopy, herbaceous and woody fuels in post-beetle stands across the GYE with TSB in both forest types. To determine how the behavior and severity of recent fires (2008) were affected by the bark beetle infestation (Question 2), field studies and remote sensing are being used to determine how actual spatial variation of fire severity across the landscape was related to pre-fire beetle infestation. A portion of the field sampling was completed during summer 2010 and summer 2011. To evaluate the effects of a short-interval fire in lodgepole pine forest (Question 3), we sampled tree regeneration and dead wood biomass in the Bearpaw Fire perimeter, and will be comparing these data to those from other recent fires that burned through mature forests (longinterval fire).

\section{Field Measurements}

Question 1. In each 0.25-ha plot, we quantified the tree (DBH or height if $<1.4 \mathrm{~m}$ tall; live / dead; quantity of red needles; presence / absence beetle galleries and pitch tubes; crown base height) and understory (\% cover and height in twenty $1-\mathrm{m}^{2}$ quadrats) layers. Surface fuels were sampled in ten 20-m transects using Brown's planar intercept method (Brown 1974). In 2011 we used these surface and canopy fuels data to parameterize the FCCS fire model (Ottmar et al. 2007) to estimate potential fire behavior in our plots. We produced vertical profiles of canopy bulk density for each plot, using fieldmeasured crown base height, and crown fuel biomass estimated from DBH and allometric relationships (Brown 1978). We used these profiles to derive effective canopy bulk density and canopy base height following Scott and Reinhardt (2001).

Question 2. Field studies were conducted in the Gunbarrel Fire, which burned $\sim 22,000$ ha in beetle-killed Douglas-fir on the SNF in 2008 (Figure 1). Using the maps of beetle kill for the GYE derived from remote sensing (described below) and field 
reconnaissance, our approach was to locate areas of heterogeneous pre-fire beetle severity within the fire area. We established 85 points in the Gunbarrel Fire. Fire severity was evaluated at each point using 30-m diameter plots, which were designed specifically for studies incorporating remote sensing. We also measured pre-fire stand density, basal area, severity of bark beetle attack and fire, and regeneration, as we have done in previous post-fire studies (e.g., Turner et al. 1997, 1999).

Question 3. We measured tree regeneration and dead wood biomass in 8 plots within the Bearpaw Fire perimeter. Each plot was 0.25-ha in size, comprising three parallel, $50 \times 2 \mathrm{~m}$ transects in which all prefire trees were sampled for size class and cone serotiny level. Tree seedlings were tallied by species and herbaceous vegetation quantified by percent cover in each of five $0.25-\mathrm{m}^{2}$ quadrats spaced evenly along each transect. Dead down wood was sampled in ten 20-m transects using Brown's planar intercept method (Brown 1974).

\section{$\downarrow \quad$ PRELIMINARY RESULTS}

Questions 1-3. Analysis of the field data collected during summer 2011 is ongoing. Results will be presented at the summer 2012 annual meeting of the Ecological Society of America.

\section{$\uparrow \quad$ ACKNOWLEDGEMENTS}

This research was funded by the Joint Fire Science Program (JFSP) and facilitated by Roy Renkin (Yellowstone National Park) and Diane Abendroth (Grand Teton National Park), as well as the Bridger-Teton and Shoshone National Forests. We appreciate the opportunity to lodging and laboratory facilities at the UW-NPS Research Station for a portion of our 2011 field season.

\section{$\uparrow \quad$ Literature Cited}

Brown JK. 1974. Handbook for inventorying downed woody material. Gen. Tech. Rep. INT-16, USDA Forest Service Intermountain Forest and Range Experiment Station Ogden, UT.

Brown JK. 1978. Weight and density of crowns of Rocky Mountain conifers. Res. Pap. INT197, USDA Forest Service Intermountain Forest and Range Experiment Station Ogden, UT.
Jenkins MJ, Hebertson E, Page WG, Jorgensen CA. 2008. Bark beetles, fuels, fires and implications for forest management in the Intermountain West. Forest Ecology Management. 254:16-34.

Keane RE. 2008. Biophysical controls on surface fuel litterfall and decomposition in the northern Rocky Mountains, USA. Canadian Journal of Forest Research. 38:1431-1445.

Lynch HJ, Renkin RA, Crabtree RL, Moorcroft PR. 2006. The influence of previous mountain pine beetle (Dendroctonus ponderosae) activity on the 1988 Yellowstone fires. Ecosystems. 9:1318-1327.

Miller JD, Thode AE. 2007. Quantifying burn severity in a heterogeneous landscape with a relative version of the delta Normalized Burn Ratio (dNBR). Remote Sensing. Environmental. 109:66-80.

Negron JF, Bentz BJ, Fettig CJ, Gillette N, Hansen E, Matthew E, Hayes JL, Kelsey RG, Lundquist Je, Lynch AM et al. 2008. US Forest Service bark beetle research in the western United States: looking toward the future. Journal of Forestry Sept:325-331.

Ottmar RD, Sandberg DV, Riccardi CL, Prichard SJ. 2007. An overview of the Fuel Characteristic Classification System Quantifying, classifying, and creating fuelbeds for resource planning. Canandian Journal of Forest Research. 37: 2383-2393.

Page WG, Jenkins MJ. 2007a. Mountain pine beetleinduced changes to selected lodgepole pine fuel complexes within the intermountain region. Forest Science. 53:507-518.

Page WG, Jenkins MJ. 2007b. Predicted fire behavior in selected Mountain pine beetle-infested lodgepole pine. Forest Science. 53:662-674.

Scott JH, Reinhardt ED. 2001. Assessing crown fire potential by linking models of surface and crown behavior. Res. Pap. RMRS-RP-29, USDA Forest Service Intermountain Forest and Range Experiment Station Ogden, UT.

Simard M, Turner MG, Griffin JM, Romme WH. 2011. Do mountain pine beetle outbreaks change the probability of active crown fire in lodgepole pine forests? Ecological Monographs. 81:3-24. 
165

Turner MG, Romme WH, Gardner RH. 1999. Prefire heterogeneity, fire severity, and early postfire plant reestablishment in subalpine forests of Yellowstone National Park, Wyoming. International Journal of Wildland Fire 9:21-36.

Turner MG, Romme WH, Gardner RH Hargrove WW. 1997. Effects of fire size and pattern on early succession in Yellowstone National Park. Ecology Monographs. 67:411-433.
Westerling AL, Hidalgo HG, Cayan DR, Swetnam TW. 2006. Warming and earlier spring increase western U.S. forest wildfire activity. Science. 313:940-943.

Wulder MA, White JC, Bentz B, Alvarez F Coops N. 2006. Estimating the probability of mountain pine beetle red attack damage. Remote Sensing of the Environment. 101:150 